\title{
Role of Follicle-stimulating Hormone Receptor Gene (ser680asn) Polymorphism in Patients with Polycystic Ovarian Syndrome
}

\section{Shilpa Kumar' ${ }^{1}$, Anju Jain ${ }^{2}$, Binita Goswami ${ }^{3}$, Abha Singh ${ }^{4}$}

\begin{abstract}
'Department of Biochemistry, Symbiosis International (deemed University), Symbiosis Medical College for Women, Pune, India; 'Department of Biochemistry, Lady Hardinge Medical College \& Smt. Sucheta Kripalani Hospital, (LHMC \& SSKH), New Delhi, India; ${ }^{3}$ Department of Biochemistry, Maulana Azad Medical College, New Delhi, India; ${ }^{4}$ Department of Obstetrics and Gynaecology,LHMC \& SSKH, New Delhi, India.
\end{abstract}

\section{ABSTRACT}

Aim: To study the FSHR gene (Ser680Asn) polymorphism in women with the polycystic ovarian syndrome (PCOS) \& healthy controls and to correlate with hormonal parameters.

\section{Methodology}

Design \& Setting: Hospital-based Cross-sectional observational Study

Patients: 30 diagnosed cases of PCOS and 30 age-matched healthy controls.

Main Outcome Measure(s): FSHR gene (ser680asn) polymorphism genotype, Hormonal Levels: FSH, LH, Prolactin, Testosterone, DHEAS

Results: LH, LH: FSH ratio and Testosterone levels were found to be significantly higher in women with PCOS compared to their healthy counterparts ( $p$-value<0.001). No significant difference was seen in the genotypic distribution of the FSHR gene (ser680asn) polymorphism between cases and controls. Inter-genotypic variation of FSH levels was observed in cases, with the GG genotype $(9.21 \pm 1.07 \mathrm{IU} / \mathrm{L})$ showing significantly higher levels compared to $A G$ genotype $(5.78 \pm 0.46 \mathrm{IU} / \mathrm{L})$ with a p-value of 0.024 .

Conclusion: The FSHR gene (ser680asn) polymorphism does not show any differential distribution between PCOS and healthy women. FSH levels, however, are influenced by the FSHR gene (ser680asn), as the serine variant of the polymorphism has higher FSH levels compared to the asparagine variant. This polymorphism could contribute to the flawed folliculogenesis in PCOS.

Key Words: Follicle-stimulating hormone, Polycystic ovary syndrome, Luteinizing hormone

\section{INTRODUCTION}

Since 1935, polycystic ovary syndrome (PCOS) is one of the most common endocrinological disorder affecting almost one in every five women of reproductive age group. Prevalence in India varying approximately between 4 to $20 \%$. The variation is attributed to the different diagnostic criteria available for this complex disease. ${ }^{1}$ It predisposes women to a whole gamut of long term complications, encompassing type 2 diabetes mellitus, dyslipidemia, hypertension, cardiovascular diseases, endometrial cancer and ovarian cancer. ${ }^{2}$ Although an overall altered hormonal milieu is responsible for defective ovarian maturation, follicle-stimulating hor- mone (FSH) remains one of the most important hormonal regulators. ${ }^{2}$ In PCOS, the average lifespan of the developing follicles increasing to span a time of several months. These follicles are immature and fail to develop. This occurs due to the presence of low but constant levels of FSH, leading to the stimulation of multiple follicles but incapable of normal maturation. These are arrested at various stages of development, leading to the characteristic appearance of multiple follicular cysts on ultrasonography. ${ }^{3}$ This follicular arrest is the hallmark of PCOS. Any factor affecting the sensitivity of follicles to FSH will indirectly affect the selection of the dominant follicle. The important role of the FSH receptor in signal transmission makes its gene an important candi-

\section{Corresponding Author:}

Dr. Shilpa Kumar, Department of Biochemistry, Symbiosis International (deemed University), Symbiosis Medical College for Women, Lavale, Mulshi, Pune, India; Phone: 09953261637; Email: shilpakumar89@gmail.com

ISSN: 2231-2196 (Print)

Received: 16.03 .2020
ISSN: 0975-5241 (Online)

Revised: 07.05 .2020

Accepted: 06.07 .2020
Published: 08.08 .2020 
date for understanding $\mathrm{PCOS}^{4}$. Furthermore, polymorphisms involving the (FSHR) have shown great clinical relevance, ${ }^{5}$ by influencing FSH action on the ovary. ${ }^{6,7}$ The FSHR gene (Ser680Asn) polymorphism, being one such SNP, has shown the serine variant to be resistant to FSH action. Therefore, studying the role of this polymorphism in patients with PCOS may help in elucidating the molecular basis of defective follicular maturation in this multi-factorial disease.

\section{MATERIALS AND METHODS}

\section{Subjects}

Institutional ethical clearance and bilingual informed consent were taken before enrolling subjects in the study. Cases and controls were recruited from Smt. SuchetaKriplani Hospital, Department of Obstetrics and Gynaecology. Participants included 30 diagnosed cases of PCOS and 30 healthy volunteers with a history of normal menstrual cycles. Patients were diagnosed based on revised guidelines of PCOS Consensus Workshop Group held at Rotterdam in $2003{ }^{8}$ Women diagnosed with diabetes mellitus, hypothyroidism, hyperprolactinemia, androgen-secreting tumours and related hormonal disorders were excluded.

\section{Hormonal Analysis}

Serum samples on day 2 to 5 of the menstrual cycle were analyzed for follicle-stimulating hormone (FSH), Luteinizing Hormone ( $\mathrm{LH})$, Prolactin and testosterone using an electro-chemiluminescence immunoassay (ECLIA). Dehydroepiandrosterone sulfate (DHEAS) was analysed using enzyme-linked immunosorbent assay(ELISA).

\section{Genotype Analysis}

Blood sample for genotype analysis was collected in EDTA vacutainer and stored at $-20^{\circ} \mathrm{C}$. Extraction of genomic DNA was done using Qiagen kit. Genotyping for FSHR gene (Ser680Asn) was done using PCR-RFLP. The primer pair used for amplification was 5'- GCA AGT GTG GCT GCT ATG AA-3' (forward) and 5'-GCA CTG TCA GCT CTT TGT GA-3' (reverse) in a $25 \mu 1$ mix. PCR cycling parameters used were, initiation at $95^{\circ} \mathrm{C}$ for 5 minutes, 35 cycles at $95^{\circ} \mathrm{C}$ for $30 \mathrm{sec}, 60^{\circ} \mathrm{C}$ for $30 \mathrm{sec}$, and $72^{\circ} \mathrm{C}$ for 1 minute followed by a final extension at $72^{\circ} \mathrm{C}$ for 10 minutes. After digesting the products with $\mathrm{B} s r I$ at $65^{\circ} \mathrm{C}$ for 15 minutes, DNA fragments were separated by DNA electrophoresis. $2 \%$ agarose gel stained with ethidium bromide-stained was used to visualize under ultraviolet light. The presence of the $\mathrm{G}$ allele or the serine variant created a site for the restriction enzyme Bsr I 5'ACTGGN//3' 3'TGAC//CN 5' to act and produce two bands of sizes 115 and 135 (as seen in lanes 2 and 3 of figure 1). The A allele, or the asparagine variant, not having the restriction site produced a single band of size 250bp (lane 5 in Figure 1).

\section{Statistical analysis}

Statistical analysis was performed using SPSS version 20.0. chi-square test was used to analyse the difference between genotype frequency in cases and controls. Student's t-test or Mann-Whitney $U$ test was used to analyse the difference between 2 groups and for more than two groups ANOVA or Kruskal-Wallis tests were used. Post-hoc analysis was conducted using Tukey's test to find out which individual groups showed significance. A $p$-value of $<0.05$ was considered statistically significant.

\section{RESULTS}

The mean age of PCOS patients, in years, was $(23.9 \pm 3.2)$ compared to $(24.5 \pm 4.6)$ Table 1 shows the hormonal profile of the study groups. LH, LH/FSH ratio and testosterone were found to be significantly higher in cases compared to controls with a $p$-value of $<0.001$. The genotypic distribution for FSH receptor polymorphism (Ser 680Asn) was in HardyWeinberg equilibrium. On applying the chi-square test, no statistical difference was found in the genotype frequency of the polymorphism between patients and controls (Table 2). Inter-genotypic variation of FSH levels (Table 3) was significant $(p$-value $=0.030)$, where GG genotype $(9.21 \pm 1.07$ IU/L) had higher levels of FSH when compared to AA (6.91 $\pm 0.58 \mathrm{IU} / \mathrm{L})$ and $\mathrm{AG}(5.78 \pm 0.46 \mathrm{IU} / \mathrm{L})$. The difference in posthoc analysis (Tukey) was significant only between GG and $A G(p$-value $=0.024)$.

\section{DISCUSSION}

The prevalence of polycystic ovarian syndrome of up to $18 \%{ }^{1}$ translates to an average of one in five women to be affected with the syndrome. This burden of the disease along with its long term consequences, such as diabetes mellitus, metabolic syndrome and cancer stress the urgent need to comprehend its intricacies. Analysis of the genes associated will, therefore, help in understanding its molecular etiology. Since FSH plays a pivotal role in folliculogenesis, one of the major defects encompassing the syndrome, the FSHR gene becomes a promising gene with great implications. It not only helps in understanding disease pathogenesis but may also in implementing evidence-based medicine when it comes to treating patients of infertility with recombinant FSH. Some studies have even concluded FSHR gene genotype as an important contributing factor for the determination of the prognosis of controlled ovarian hyper-stimulation cycles. ${ }^{9}$ The present study attempted to reveal any contributions of this resistant $F S H R$ gene variant in the pathogenesis of PCOS.

The study by Gu B et al. ${ }^{10}$ in Korea, found a significant association of the FSH receptor gene (ser680asn) polymor- 
phism and PCOS ( $p$-value $=0.0195, \mathrm{OR}=1.66$ ). Sudo et al. ${ }^{11}$ studied the FSH receptor gene polymorphisms (ser680asn) and (ala307thr), and found a significant correlation of the Ala307 and Ser680variantswith PCOS. Another study by J. Laven et al. ${ }^{12}$ also found the homozygous Serine variant at 680 (GG) to be significantly associated with WHO type II amenorrhea. Valkenburg et al ${ }^{13}$ found FSHR gene variants to be associated with the severity of clinical features in PCOS features, but they did not report it to contribute to an increase in disease risk. Other studies of the polymorphism in PCOS, by $\mathrm{Fu} \mathrm{L}$ et al. ${ }^{5}$ and $\mathrm{Wu} \mathrm{XQ}$ et al. in China ${ }^{6}$, Kambalachenu et al. ${ }^{14}$ in South India, Mohiyideen L et al. ${ }^{15}$ and Conway GS et al. ${ }^{16}$ in the UK found no association of the FSH receptor gene (ser680asn) polymorphism with PCOS. The present study had similar results with a $p$-value of 0.274 , not showing any association between the polymorphism and the presence of PCOS. Research on this polymorphism all over the world has shown contradictory results when associating it with PCOS, but most have observed inter genotypic variation of FSH levels.

Although the association between the FSH receptor gene (ser680asn) polymorphism and PCOS is insignificant, its permissive role in contributing to chronic anovulation cannot be entirely ignored, as the polymorphism displays its effect on basal FSH levels. Mayorga et al. ${ }^{17}$ and Jun JK et al. ${ }^{10}$, reported lower ovarian response in the GG genotype when studying women undergoing controlled ovarian hyperstimulation for In vitro fertilization. The basal level of FSH in these patients was significantly high in the group with GG genotype. Similarly, in studies on PCOS women by Wu XQ et al. ${ }^{6} \mathrm{Fu} \mathrm{L}$ et al. ${ }^{5}$ and Valkenburg et al. ${ }^{14}$ higher levels of FSH levels were observed in the GG genotype. The present study also found that patient groups with the homozygous GG genotype had significantly higher levels of FSH compared to their heterozygous counterparts. The GG genotype has a mean FSH value of $(9.21 \pm 1.07 \mathrm{IU} / \mathrm{L})$ compared to $(5.78 \pm 0.4 \mathrm{IU} / \mathrm{L})$ in $\mathrm{AG}$ genotype and $(6.91 \pm 0.58 \mathrm{IU} / \mathrm{L})$ in AA genotype. The p-value for this difference was 0.024 between genotypes AG and GG. The GG genotype introduces a potential phosphorylation site (serine residue) in the intracellular domain of the FSH receptor. This promotes the binding of the receptor to inhibitor proteins called arrestins, which interrupts the interaction between the receptor and $\mathrm{G}$ protein, thereby reducing FSH action..$^{18}$ As a result, a higher amount of FSH is required to bring about the same biological action, as is observed by the increased levels of basal FSH in patients with the GG genotype.

Greb et al. ${ }^{19}$ conducted a study assessing this genotype and concluded that a higher ovarian threshold was associated with the GG genotype of the FHS receptor. Along with this they also reported this group to have longer menstrual cycles and their luteal secretion providing lower feedback to the pituitary in between the cycles. This polymorphism has been concluded by many studies (Moron and Ruiz ${ }^{20}$ Altmae et al. ${ }^{21}$ and Yao et al. ${ }^{22}$ to be capable of having a role in translational medicine by predicting patient response to FSH stimulation. The present study also supports this statement, by revealing the role played by the FSH receptor genotype on FSH levels. Although the limited sample size in the study sets a drawback in establishing finer association within the genotypes, the presence of inter-genotypic variation of FSH levels indicates some degree of resistance conferred to the receptor, by the presence of the amino acid serine instead of asparagine.

\section{CONCLUSION}

The FSHR gene (ser680asn) polymorphism does not show any differential distribution between PCOS and healthy women. FSH levels, however, are influenced by the FSHR gene (ser680asn), as the serine variant of the polymorphism has higher FSH levels compared to the asparagine variant. The serine variant (GG), with higher FSH levels, depicts an FSH resistant receptor, consequently contributing to impaired follicular maturation. Nevertheless, a study with a greater sample size would greatly help in enhancing the understanding of FSH interaction with different FSH receptor variants. This polymorphism could contribute to the flawed folliculogenesis in PCOS.

Acknowledgement: Authors acknowledge the immense help received from the scholars whose articles are cited and included in references to this manuscript. The authors are also grateful to authors/editors/publishers of all those articles, journals and books from where the literature for this article has been reviewed and discussed.

Funding: This work was supported by the Indian Council of Medical Research

\section{Conflict of interest: None}

\section{REFERENCES}

1. Ganie MA, Vasudevan V, Wani IA, Baba MS, Arif T, Rashid A. Epidemiology, pathogenesis, genetics \& management of polycystic ovary syndrome in India. Indian J. Med. Res 2019;150(4):333-44.

2. Durlinger L, Gruijters G, Pietkramer, Baskarels, Kumar TR, Matzuk MM et al. Anti-mullerian hormone attenuates the effects of FSH on follicle development in the mouse ovary. Endocrinology. 2001;142(11):4891-9.

3. Franks S, White DM. Prevalence of and etiological factors in polycystic ovarian syndrome. Ann N Y AcadSci1993;687:112-4.

4. Fu L, Zhang Z, Zhang A, Xu J, Huang X, Zheng Qet al. Association study between FSHR Ala307Thr and Ser680Asn variants and polycystic ovary syndrome (PCOS) in Northern Chinese Chan women. J. Assist Reprod. Genet. 2013;30(5):717-21.

5. Wu XQ, Xu SM, Liu JF, Bi XY, Wu YX, Liu J. Association between FSHR polymorphisms and polycystic ovary syndrome 
among Chinese women in north China. J Assist. Reprod. Genet. 2014;31(3):371-7.

6. Conway GS.Clinical manifestations of genetic defects affecting gonadotrophins and their receptors.Clin. Endocrinol. 1996;45(6):657-63.

7. Gromoll, J, Simoni M, Nieschlag E. An activating mutation of the follicle-stimulating hormone receptor autonomously sustains spermatogenesis in a hypophysectomized man. J ClinEndocrinolMetab 1996;81(4):1367-70.

8. Rotterdam ESHRE/ASRM-sponsored PCOS consensus workshop group. Revised 2003 consensus on diagnostic criteria and long-term health risks related to polycystic ovary syndrome. FertilSteril. 2004;81(1):19-25.

9. Jun JK, Yoon JS, Ku SY, Choi YM, Hwang KR, Park SY et al. Follicle-stimulating hormone receptor gene polymorphism and ovarian responses to controlled ovarian hyperstimulation for IVF-ET. J Hum Genet. 2006;51(8):665-70.

10. Gu BH, Park JM, Baek KH. Genetic variation of follicle stimulating hormone receptor are associated with polycystic ovary syndrome.Int J Mol Med 2010; 26(1):107-12.

11. Sudo S, Kudo M, Wada S, Sato O, Hsueh AJ, Fujimoto S. Genetic and functional analyses of polymorphisms in the human FSH receptor gene. Mol Hum Reprod. 2002;8(10):893-9.

12. Simoni M, Neischlag E, Gromoll J. Isoforms and single nucleotide polymorphisms of the FSH receptor gene: implications for human reproduction. Hum Reprod. 2002;8(5):413-421.

13. Valkenburg O, Uitterlinden AG, Piersma D, Hofman A, Themmen AP, de Jong FH et al. Genetic polymorphisms of GnRH and gonadotrophichormone receptors affect the phenotype of polycystic ovary syndrome. Hum Reprod. 2009;24(8):2014-22.

14. Kambalachenu HR, Paul SFD, Nellepali SR, Venkatachalam P. Study on follicles stimulating hormone receptor gene polymorphisms in South Indian women with polycystic ovarian syndrome.Amer. Med J. 2013;4(2):16-7.
15. Mohiyiddeen L, Salim S, Mulugeta B, McBurney H, Newman WG, Pemberton $\mathrm{P}$ et al. PCOS and peripheral AMH levels in relation to $\mathrm{FSH}$ receptor gene single nucleotide polymorphisms. Gynecol.Endocrinol. 2012;28(5):375-7.

16. Conway GS, Conway E, Walker C, Hoppner W, Gromoll J, Simoni, M. Mutation screening and isoform prevalence of the follicle stimulating hormone receptor gene in women with premature ovarian failure, resistant ovary syndrome and polycystic ovary syndrome.Clin. Endocrinol. 1999;51(1):97-9.

17. Mayorga MP, Gromoll J, Behre HM, Gassner C, Nieschlag E, Simoni M. Ovarian response to follicle-stimulating hormone stimulation depends on the FSH receptor genotype. J of Clin. Endocrinol.Metab. 2000;85(9):3365-9.

18. Simoni M, Gromoll J, Nieschlag E. The follicle-stimulating hormone receptor: Biochemistry, molecular biology, physiology and pathophysiology. Endocr. Rev. 1997;18(6):739-73.

19. Greb RR, Grieshaber K, Gromoll J, Sonntag B, Nieschlag E, KieselSimoni M. A common single nucleotide polymorphism in exon 10 of the human follicle stimulating hormone receptor is a major determinant of length and hormonal dynamics of the menstrual cycle. J Clin. Endocrinol. Metab. 2005;90(8):4866-4872.

20. Moron FJ, Ruiz A. Pharmacogenetics of controlled ovarian hyperstimulation: time to corroborate the clinical utility of FSH receptor genetic markers. Pharmacogenomics. 2010;11(11):16138.

21. Altmae S, Hovatta O, Stavreus-Evers A, Salumets A. Genetic predictors of controlled ovarian hyperstimulation: where do we stand today? Hum Reprod Update. 2011;17(6):813-28.

22. Yao Y, Ma CH, Tang HL, Hu YF. Influence of follicle-stimulating hormone receptor (FSHR) Ser680Asn polymorphism on ovarian function and in-vitro fertilization outcome: a meta-analysis. Mol. Genet. Metab. 2011;103(4):388-393.

Table 1: Hormonal Parameters of the Study Group

\begin{tabular}{lccc} 
Parameter & Cases $(\mathbf{n}=\mathbf{3 0})$ & Controls $(\mathbf{n}=\mathbf{3 0})$ & p-value \\
TSH $(\mu \mathrm{IU} / \mathrm{ml})$ & $2.94 \pm 0.23$ & $2.46 \pm 0.17$ & 0.171 \\
LH $(\mathrm{IU} / \mathrm{L})$ & $16.6 \pm 1.5$ & $6.3 \pm 0.5$ & $<0.001^{*}$ \\
FSH $(\mathrm{IU} / \mathrm{L})$ & $7.0 \pm 0.5$ & $7.6 \pm 0.3$ & 0.246 \\
LH:FSH Ratio & $2.42 \pm 0.18$ & $0.83 \pm 0.05$ & $<0.001^{*}$ \\
Prolactin $(\mathrm{ng} / \mathrm{ml})$ & $22.3 \pm 1.8$ & $18.1 \pm 1.4$ & 0.109 \\
Testosterone $(\mathrm{nmol} / \mathrm{L})$ & $1.68 \pm 0.12$ & $0.92 \pm 0.09$ & $<0.001^{*}$ \\
DHEAS $(\mu \mathrm{g} / \mathrm{ml})$ & $2.54 \pm 0.20$ & $2.23 \pm 0.22$ & 0.842 \\
\hline
\end{tabular}

${ }^{*} p$-value significant at $<0.05$

Table 2: Genotypic Distribution of FSH Receptor Gene (Ser68oAsn) Polymorphism in Cases and Controls

\begin{tabular}{lccccc} 
Genotype & \multicolumn{2}{c}{ Cases $(\mathbf{n}=30)$} & \multicolumn{2}{c}{ Controls $(\mathbf{n}=30)$} & p-value \\
& $\mathbf{n}$ & $\%$ & $\mathbf{n}$ & 33.33 & \\
AA & 15 & 50 & 10 & 16.66 & 0.274 \\
GG & 6 & 20 & 5 & 15 & 50 \\
AG & 9 & 30 & & 15 & \\
\hline
\end{tabular}


Table 3: Inter-genotypic variation of FSH Levels in Cases

\begin{tabular}{lccc} 
Genotype & $\begin{array}{c}\text { Cases }(\mathbf{n}=30) \\
\text { Mean } \pm \text { SEM }\end{array}$ & \multicolumn{2}{c}{ Comparison between Genotypes $^{\text {b }}$} \\
AA & $6.91 \pm 0.58$ & GG & 0.118 \\
GG & $9.21 \pm 1.07$ & AG & $0.024^{*}$ \\
AG & $5.78 \pm 0.46$ & AA & 0.488 \\
$0.030^{a^{*}}$ & & & \\
\hline
\end{tabular}

aANOVA

${ }^{\text {bPost-hoc Test }}$

${ }^{*} p$-value significant at $<0.05$

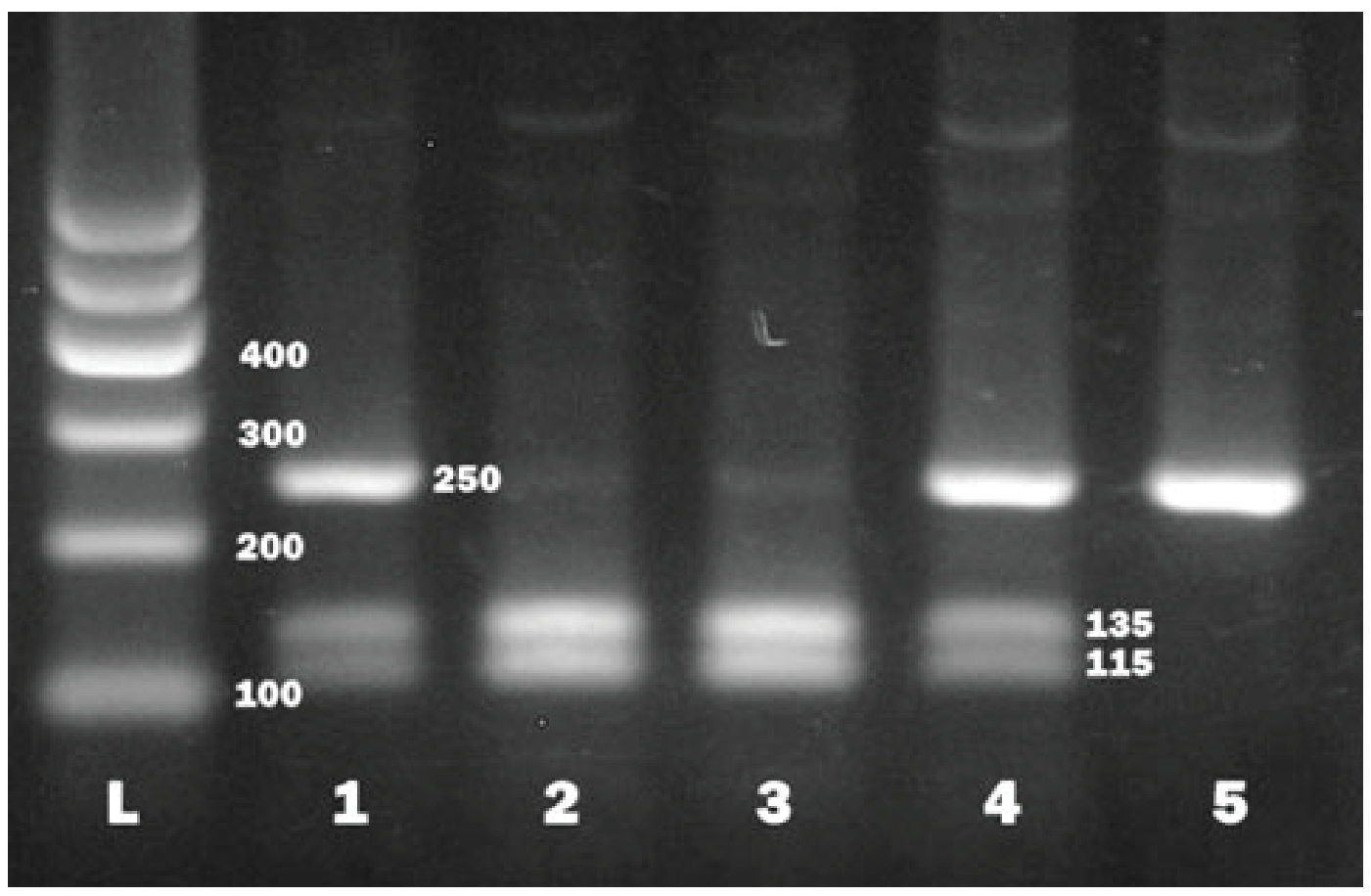

Figure 1: Genotyping for FSHR gene (Ser680Asn) using PCR-RFLP after digestion with Bsr land electrophoresis on ethidium bromide stained $2 \%$ agarose gel.

Left lane (L), 100 bp ladder. Lane 5: Homozygous AA genotype showing 250bp band of the undigested PCR amplicon. Lane 2 \& 3: Homozygous GG genotype results in two bands of 115bp \& 135bp. Lane 1 \&4:Heterozygous AG genotype results in three bands of 250bp, $115 \mathrm{bp} \& 135 \mathrm{bp}$. 